\title{
Implementation of Social Inquiry Learning Strategy to Improve Social Studies (IPS) Achievement of Students Class IV SDN No. 84 Parepare
}

\author{
Amir Pada ${ }^{1}$, Hasna ${ }^{2}$, Jonathan S. Pasinggi ${ }^{3}$ and Suriani Lukman ${ }^{4}$ \\ \{ amirpadda30@gmail.com $^{1}, \underline{\text { hasna@ unm.ac.id }}$, $\underline{\text { Jonathan@unm.ac.id }}$, $\underline{\text { surianilukman@ @mail.com }}^{4}$ \}
}

Prodi PGSD Fakultas Ilmu Pendidikan UNM, Indonesia

\begin{abstract}
The problem of this research is whether the application of social inquiry strategies in teaching can improve students' learning achievement social studies in Grade IV students of State Elementary School No. 84 Parepare. This study aims to determine the Implementation of Social Inquiry Learning Strategies cans Improve Student Social Learning achievements. This type of research is Classroom Action Research with the procedure of implementing actions: Planning, Action, Observation and Reflection. The approach used is a qualitative approach. The population was all students of State Elementary School No.84 Parepare City, while the sample used was class IV totaling 23 people, consisting of 10 men and 13 women. The focus of the study is the Implementation of Social Inquiry Learning Strategies and Student Learning achievements in social studies subjects. Data collection techniques carried out through; observation, test and documentation. Techniques in analyzing data using descriptive qualitative. The results showed that the learning achievements of students in the first cycle were in the sufficient category fair (C) while the learning achievements of the students in the second cycle experienced changes or improvements in the good category (B). The conclusion of the study is an increase in student learning achievements in social studies subjects through the application of social inquiry strategies in State Elementary School No. 84 Parepare.
\end{abstract}

Keywords: social, inquiry, learning, students

\section{INTRODUCTION}

From the results of the needs analysis obtained information from teachers that the implementation of learning in SDN 84 Parepare so far has not optimally encouraged students to actively participate in studying the concept of social studies. So that the implications for the acquisition of learning outcomes is still low, only 34\% of 23 students reach the Minimum Score Criteria (KKM) 70.

Based on the cause of the problem, one of the efforts that can be done to improve student learning outcomes in social studies is the application of social inquiry learning strategies Social inquiry, according to Sardijoyo (2008), Somantri, (2001) explains that social inquiry is one of the learning strategies which is based on a social approach. This strategy involves 
students searching for data and facts related to the material and social problems in the surrounding their environment.

Using of social inquiry learning strategies to solve problems in social learning is very suitable because according to Nasution (2013: 81) that: a). This strategy is specifically designed to improve students' abilities and skills in finding social concepts or problems, b). Some research results show that this strategy has been proven effective in increasing students' abilities and skills in solving social problems, c). This strategy is a synchronization between teaching theory and learning theory, which has procedures that are systematic and easily applied by teachers.

Social inquiry learning strategies according to Barr (1977) is as a general process by humans to search for or find information. Druckman, D (2005) stated that Social inquiry learning strategies are a series of learning activities that emphasize the process of thinking critically and analysing themselves to find and find answers to a problem in question. Bobbi (2009) stated that social inquiry can gradually improve students' critical abilities towards a problem being solved.

The application of social inquiry strategies in social studies learning still refers to the principles that have been determined. According to Dwyer (1978) the principles of inquiry are: intellectual principles, interaction, asking questions, learning to think and being open. Wena (2009), Druckman, D. (2005) stated the stage in the application of social inquiry strategies, namely: 1) presentation, 2) hypothesis 3) definition, 4) exploration, 5) collection of data / information and 6) generalization.

Implementation of the applying the social inquiry model in social studies learning is carried out through three stages of learning, namely: a) initial activities, the teacher conveys the learning objectives to be achieved. b) the teacher gives information about the problem, students express their provisional assumptions about the problem, students look for the truth of the answers submitted, students discuss the findings in groups, then students report the findings of each group in front of the class in turn. The teacher gives reinforcement to the results of group work. 3) And conducting follow-up and evaluating to measure learning success.

Students learning achievement are behavioural changes obtained by students after experiencing learning activities. To measure learning achievements must be in accordance with the goals of cognitive, affective, and psychomotor achievement According to Ali (2002), learning outcomes in the form of changes in behaviour, both concerning cognitive, affective, and psychomotor ". According to Winkel (1989: 82) learning outcomes are the success achieved by students, namely student learning achievements in schools that are realized in the form of numbers or evidence of success that has been achieved.

According to Druckman (2005) that learning achievement for most people or the results of tests can be used to determine the index and success of students. The success index is obtained by using several types of instruments, one of which is multiple choice questions. The advantage of this type of test is that it is able to accommodate / measure all the material taught. Because of that through this research to measure student learning achievement used multiple choice test instruments, with the hope of recording student mastery of the material being studied as a whole.

Learning achievement by these students become indicators to determine the ability, capability, mastery of knowledge of each student. It was made clear by Suryanto (2009) that 
learning achievement are everything that belongs to students as a result of the learning activities they do.

This research use descriptive qualitative approach. This type of research is classroom action research with Elliot's cycle recycling proses (1993). The focus of this research is the process of implementing social inquiry learning strategies in social studies learning and student learning outcomes after the final test given in each cycle. Subjects in this study were teachers and class IV SDN 84, the 2018-2019 academic year with totalling 23 people, consisting of 10 men and 13 women. Research procedures include: Planning, implementation of action, observation and reflection.

The procedures of collection data, which are used are: observation, testing and documentation Margono (2007: 158). Techniques analysing data and indicators of success using descriptive qualitative, by Milles and Hubberman (Emzir, 2010) which include: Data reduction, Data presentation, Verification / Drawing conclusions.

Indicators of research success include: the process is said to be successful if $76 \%$ of the social inquiry learning strategy steps are carried out well based on a predetermined qualification format and results: said to be successful if 20 out of 23 students score greater than the minimum completeness criterion score of 76.

\section{FINDINGS}

This research starts from the students achievement in learning social studies subjects is low, which is caused by the use of strategies in social studies learning that has not been carried out optimally, the methods applied have not varied and do not provide opportunities for students to construct their own knowledge so that it impacts on the quality of social studies learning achievement. The pre-research learning document data shows that there are still many IPS students' scores below the Minimum Score Criteria (76). The description of student learning outcomes before applying the social inquiry strategy in social studies learning is an average of 62.04 meaning the value of social studies subjects does not meet the Minimum Score Criteria (KKM). This learning phenomenon needs to be improved by the use of social inquiry strategies in learning through classroom action research.

Furthermore, descriptions of student learning achievements after the use of social inquiry strategies in social studies learning through this study are:

\section{Implementation of the First Cycle}

Description of student learning achievemnet in social studies subjects the first cycle shows an average value of 73.47 , if converted to success criteria, the value is categorized Enough (C). Research data proves that there is an increase in learning outcomes when compared with the conditions of pre-action learning outcomes, the value of these students has changed but has not yet reached the minimum score of success indicators set by the school of $76 \%$. Based on the results of the reflection, the research success data was declared to be unsuccessful, the cause of the teacher at the stage of export was only to urge students to look for the concept of social problems limited to just one textbook, so students gained less knowledge. The results of reflection on the implementation of learning and the lack of implementation of the steps to apply the social inquiry strategy become the reference material for the action in the implementation of next cycle.

\section{Implementation of the Second Cycle}


Data on the results of evaluating student learning after the process of implementing the second cycle of actions obtained an average value of students that is 91.73 with the distribution of the percentage of student learning achievement in this cycle as follows: from 23 students there are 21 students who get good grades (76-100\%), 2 students who get enough grades $(60-75 \%)$, and no students who scoreless $(0-59 \%)$. The data proves that the learning outcomes of students in the second cycle reached $91 \%$ in the good category (B), which means that the Minimum Score Criteria target had reached 75. The results of the analysis and reflection were concluded that the implementation of the social inquiry strategy had been done well, so the research had to be stopped. The student learning achievement data prove that by implementing social inquiry strategies in social studies learning can be improved student learning achievement in elementary schools.

\section{DISCUSSION}

Students learning achievement are changes in behaviour obtained by students after experiencing learning activities. To measure learning achievement must be in accordance with the goals of cognitive, affective, and psychomotor achievement that are tailored to students' abilities. According to Ali (2002) stated that learning outcomes in the form of changes in behaviour, both related to cognitive, affective, and psychomotor. According to Winkel (1989: 82) learning achievement are the success achieved by students, namely student learning achievements in schools that are realized in the form of numbers as evidence of success achieved.

Learning achievements achieved by students become indicators of knowing abilities, capabilities, mastery of expected knowledge. Barr and Shermis. (1977) argues that learning achievements are everything that belongs to students as a result of learning activities. But the increase in learning achievement is influenced by two factors, namely: a) internal factors include psychological conditions such as intellectual abilities that include knowledge absorbed by students. Acquisition of aspects of knowledge according to Woolfolk, (2008) occurs in an emotional state able to socialize with the environment, able to access information / material that are relevant to the needs in the community. b) External factors that affect learning conditions such as places of study, climate, the atmosphere of the environment and the culture of learning. The nuance of learning that is expected in the application of social inquiry strategies is the creation of a conducive and pleasant climate and learning culture.

The success of social studies learning can be measured by the high or low score of student learning achievements in certain subjects. Through classroom action research conducted at 84 Parepare Public Elementary Schools by applying social inquiry strategies obtained authentic data that the value of student learning achievements and activities in social studies learning has increased.

Data on student activeness in the first cycle with enough categories while the second cycle is already in the good category proves that the frequency of student activity from one cycle to the next cycle has increased, the increase is due to the teacher being able to implement social inquiry strategy steps appropriately. This finding is supported by Dewey's (2009) view which states students tend to actively interact if what they are doing is interesting.

Acciording to Dwyer (1998) that the absorption of high learning is physically and emotionally involved in student learning. Learning by applying inquiry strategies affects 
students' high memory on subject matter Banks (1990), Porter (2001) if the application of learning strategies is structured based on the flow of the learning strategy set.

Student learning achievements data based on the results of the first cycle test on social studies learning using social inquiry strategies show the criteria Fair. This student's score proves that learning has not yet reached the learning Minimum Score Criteria (KKM), so learning needs to be continued into the next cycle, Kunandar (2008), Strianger, Ernest T. (1996).

Student learning achievements on the second cycle of learning with Good criteria (B) have experienced significant changes, this proves that there is an increase when compared with learning in the previous cycle. The successful implementation of this strategy is because the teacher is able to apply the steps of inquiry well, Banks. (1990). The above findings are supported by Irmawati's study (2013) which concluded that there was a significant increase in the use of social inquiry strategies with student learning outcomes in which the results of the study in the first cycle showed the next Fair category in the second cycle of learning that student learning outcomes were in the Good category. According to Hitchcock, G and D. Hughes. (1989), Daryanto, (2011) if learning has reached the KKM target set, the study is stopped. This means that social studies learning by using the Social Inquiry strategy can improve student learning achievements in 84 public elementary schools of Parepare.

\section{CONCLUSION AND SUGGESTION}

\subsection{CONCLUSION}

Based on the results of the implementation of research through the use of social inquiry strategies, in the learning carried out it can be concluded that: The use of social inquiry strategies in social studies learning can improve student learning achievements in SD Negeri 84 Parepare.

\subsection{SUGGESTIONS}

The results of the study by applying social inquiry methods, the researchers put forward several suggestions including:

1.For schools, especially SDN 84 Parepare, social inquiry methods can be used as an alternative in efforts to improve student learning achievements.

2. For teachers, they should be able to choose a social inquiry strategy to be used as a reference in planned learning.

3.For researchers who will research the use of inquiry methods, so that it can develop this research into research in a wider research.

\section{References}


Ali, M. 2002. Teachers in the Teaching and Learning Process. Bandung : Sinar Baru Algesido Arikunto, Suharsimi. 2006. Classroom Action Research. Jakarta : Rineka Cipta

Banks. James Amorose. 1990. Teaching Strategis for Studies Inquiri Veluing and Decission Making. Ohio Amborose Acegg Jr. Kent State Uniersity.

Barr.RD. BarthJ.L. and Shermis.S.S. 1977 Difiniting the Social Studies. Washinton DC Nasiona Council for the Social Studies

Daryanto. 2011. Classroom and School Action Research. Yogyakarta : Gava Media

De Porter, Bobbi, dan Hernacki, Milk. 2001. Quantum Learning. Diterjemahkan Oleh Alwiyah Adurrahman. Bandung: Kaifa PT Mizan Pustaka.

Dewey, John.C. 2013 Intersest end effort In Education. Boston Houghton, MC Millan.

Druckman, D. 2005. Doing Research: Methods of inquiry for conflict analisis. Oaks/California: Sage Publikation.

Dwyer Francis M., 1978 Strategis for Improving Visual Learning, State College, Pensylvania: Learning Services.

Elliott, John. 1993. Action Research For Educational Change. Open University Press: Milton Keynes - Philadelphia.

Emzir. 2010. Qualitative Research Methodology: Data Analysis. Jakarta: Rajawali Pers.

Hitchcock, G and D. Hughes. 1989. Research and the Teacher ( A qualitative introduction to school-based research) second edition. London: Routledge.

Irmawati 2014. Implementation of Social Inquiry Strategy in Social Studies Learning in SD 79 Kota Parepare Skripsi . PGSD FIP Universitas Negeri Makassar.

Kunandar. 2008. Classromm Action Research . Jakarta: Raja Grafindo Persada.

Margono, S. 2007. Educational Research Methodology. Jakarta: Rineka Cipta.

Nasution, S. 2013. Various Approaches in Learning and Teaching. Jakarta: Bumi Aksara.

Sardijoyo. dkk. 2009. Social studies education in elementary school. Jakarta : Universitas Terbuka

Somantri, M. N. 2001. Initiating renewal of social studies education, Bandung. Remaja Rosdakarya,.

Strianger, Ernest T. 1996. Action Research A Handook For Practitioners. London New Delhi: SAGE Publications

Suryanto, Adi. 2009. Learning Evaluation in Elementary School. Jakarta: Universitas Terbuka.

Trianto. 2007. Model-Model Constructivistic Oriented Learning. Jakarta: Prestasi Pustaka Wena, Made. 2009. Contemporary Innovative Learning Strategies. Jakarta: Bumi Aksara

Winkel.W.S. 2007. Teaching Psychology, Yogyakarta: Media Abadi.

Woolfolk, Anita 2008. Educational Psychology Active Learning Edition. Yogyakarta: Pustaka Pelajar. 